\title{
Suppression of Tumorigenicity 5 Protein
}

National Cancer Institute

\section{Source}

National Cancer Institute. Suppression of Tumorigenicity 5 Protein. NCI Thesaurus. Code C18284.

Suppression of tumorigenicity 5 protein $(1137 \mathrm{aa}, \sim 126 \mathrm{kDa}$ ) is encoded by the human ST 5 gene. This protein plays a role in the activation of Ras-related proteins Rab-9A and Rab-9B. 